\title{
Love in a time of Ebola: reflections on theology of medicine in resource-challenged environments
}

\author{
Andrew Sloane ${ }^{a}$
}

\begin{abstract}
${ }^{a}$ MBBS, BTh, DipMin, ThD, Senior Lecturer in Old Testament and Christian Thought, Director of Post Graduate Studies; Morling College, Australia (Australian College of Theology and University of Divinity)
\end{abstract}

\begin{abstract}
This paper presents a much needed (philosophical and) theological framework for the practice of Christian medicine in resource-challenged environments. While "health and healing" are often seen as determining the nature and goals of medicine, I believe that this distorts our understanding and practice of medicine. Rather, medicine is about care: it is an expression of a community's solidarity with people whose inherent vulnerability and finitude is exposed by the physical or psychological disruptions occasioned by disease, disability, or disaster; it aims to so care for them that their inherent worth as members of the human community is affirmed and that they are able to function well in community, where possible, and to the best of our ability in the circumstances in which we find ourselves. This both requires costly service in contexts of scarcity and informs the kind of care that ought to be provided to those in need.
\end{abstract}

\section{Introduction}

I live in Australia and, like most "Western" countries, our media is somewhat fixated on medicine and health. ${ }^{*}$ We hear of wonderful new advances in cancer treatment; of photogenic children's lives at risk because they don't have access to it; of some new multi-resistant superbug that threatens Western civilisation, and so on and so forth. Fixated, but also self-absorbed. For these stories are about us, about the possibilities and problems of medicine in our affluent environment. But for a brief period in 2013/4, these issues were pushed off the front page by a health crisis in West Africa: Ebola. For a little

\footnotetext{
* A fuller treatment of this topic and related issues can be found in my Vulnerability and Care.
}

while, even Australians felt they might be susceptible to a plague such as had not been seen since the eradication of smallpox.

The time of Ebola is, thankfully, mostly over. While 28,571 people have been infected with the virus since the outbreak began, and, tragically, 11,299 have succumbed, there have been few new cases in recent weeks. ${ }^{1}$ The crisis has passed for now and is off our front pages. But, the realities remain. Despite its sprawling illdiscipline, a novel like Marquez's Love in the Time of Cholera reminds us in the West how much endemic disease is a fact of human existence and of the ways it shapes people's lives, ${ }^{2}$ the desperate decisions it makes necessary, and the tragedies it renders unavoidable. These realities warrant careful reflection, for Ebola, or 
its like, will return. And, as a Christian, such reflection, I believe, necessarily takes theological form.

Reflection on medicine and medical practice tends to ignore underlying questions of the nature and goals of medicine; however, a Christian response to medical care in resource-challenged environments ought to reflect those fundamental Christian commitments that inform the practice of medicine, even as those contexts challenge us to develop an appropriate theological framework that might inform practice. This paper uses issues facing medicine in a global context as an entry point for philosophical and theological reflection on the nature and goals of medicine. I will begin with two case studies drawn from the recent Ebola crisis in West Africa before discussing some recent contributions to theology of medicine. Having noted gaps and weaknesses in those contributions, I will move on to outline a philosophical-theological account of medicine focusing on its nature and goals. I will close by returning to the practice of medicine in resourceconstrained conditions, aiming to suggest forms that Christian love might take in a time of Ebola.

\section{A Time of Ebola}

Let me begin with two contrasting "case studies." Kent Brantly is an American doctor who worked with Samaritan's Purse in West Africa during the Ebola epidemic. Dr Brantly joined the agency shortly after graduating from Indiana University and was deployed to Liberia to engage in medical care and relief in October 2013 prior to the outbreak of Ebola in West Africa. When the disease spread to Liberia in June 2014, he stayed in the country and, along with another doctor, was engaged in the care of people with the virus. Although he took appropriate precautions, he contracted the disease in July 2014 and was treated in Monrovia before being evacuated to the US on 2 August 2014. After receiving sophisticated medical care at Emory University Hospital, much of it unavailable in Monrovia (including the controversial and experimental drug ZMapp), he made a full recovery and was discharged on 21 August 2014. ${ }^{3}$
Brantly's is a good news story; the second case presents a tragic contrast. Sheik Umar Khan was a Sierra Leonean doctor who worked with the ministry of health in Sierra Leone during the Ebola epidemic. Dr Kahn completed his training in medicine in 2001 at the University of Sierra Leone in Freetown. He practiced in infectious diseases in West Africa, focusing on haemorrhagic fevers such as Lassa fever. When the Ebola epidemic struck, he played a major role in response through government and other agencies such as WHO and MSF. Despite known risks and limited resources, he continued to care for patients and implement public health measures. Although he, too, took appropriate precautions, he tested positive to the disease on 22 July 2014. In response to treatment, his condition initially improved, but despite hopes for a full recovery he rapidly deteriorated and died on 29 July at the Ebola Treatment Centre in Kailahun. ${ }^{4}$

So, what can we learn from these cases about medicine in resource-constrained environments? I want to leave aside questions relating to whether ZMapp should have been used in the treatment of Dr Khan (or Dr Brantly) and focus on the circumstances of their treatment. For their different treatment reflects the disparities in medical services and treatment resources available to patients in the Western and "majority" worlds. Khan was treated at the Ebola Treatment Centre in Kailahun, a field hospital in Sierra Leone; Brantly was treated at Emory University Hospital, a tertiary teaching hospital in the US. The disparities are clear: Emory's sophisticated diagnostic and therapeutic resources are simply unavailable, in fact almost unimaginable, in Kailahun. Indeed, the kind of care available to patients in a tertiary level ICU cannot be accessed in most parts of the "developing" world. This does not mean that no care is available or that the care available makes no difference - far from it - but the disparities are clear.

However, other questions are raised by these cases. For we often think of medicine as being about fighting disease and forestalling death; we believe that is its nature and its goal. If that's the 
case, then we must conclude that those who treated Brantly succeeded, while those who treated Khan failed. That can't be right. Indeed, that would imply that in the $40 \%$ of cases where patients die (and so, necessarily, medical care lost the fight against disease; it did not forestall death), the extraordinary efforts made in caring for patients with Ebola by Brantly and Khan and countless others ought to be considered failures of medical care. Surely not - tragedies, yes; failures, no.

Moreover, if we think of medicine as being about improving people's health or that of their communities, then neither case can be viewed as a success. This is clear enough in Khan's case; he died, after all. But equally, Brantly's recovery came at a cost in time, materiel, etc., that cannot be reasonably borne by all who face serious tropical disease. Indeed, the very focus on acute care, be it in Kailahun or Emory, distracts us from the fact that such care makes no significant impact on containing the spread of the disease, let alone the serious underlying health concerns of a region like West Africa. Deploying a similar amount of resources in the provision of, say, public health, sanitation, clean water, infrastructure, and even policing, would have a much greater impact on the health of these communities than if they were used in acute medical care. ${ }^{5}$ Providing safe water and sanitation alone would reduce around 9\% of the global burden of disease. $^{6}$ If medicine is about improving health, then once again, it does not seem to do its job terribly well.

Please don't get me wrong. I am not saying that the care provided to Brantly and Khan was inappropriate - nor was the care provided by them (or that it did not benefit many of the people they treated). Nor am I making the (wildly implausible) claim that health and related concerns are not medicine's concern. My point is that their cases raise important questions about the nature and goals of medicine that are not adequately addressed by defining medicine's nature and goals in terms of health. We are, I would suggest, using the wrong categories and asking the wrong questions, and so finding the wrong answers.

\section{Thinking About Health}

If a crisis like Ebola raises questions about the nature and goals of medicine, so does the very different context of the West, with its increasing commodification of health care as a consumer product and the loss of notions of the inherent morality of medicine as a profession. ${ }^{7,8}$ Most attempts to answer these questions also use "health" and "healing" as their primary categories. This means it is important to squarely address that approach in order to draw on the riches of those discussions and question their adequacy as an account of medicine. So, let me turn to the recent work of Neil Messer. ${ }^{9}$

Messer seeks to provide a foundation for bioethics and the ethics of medicine by drawing on recent philosophy of medicine and disability theory, interpreting it in light of the theological resources of the Christian tradition. He shows that "health," "disease," and "illness" are both valueladen and logically fuzzy concepts and proposes "flourishing" as the key to a properly Christian view of health. Flourishing, he argues, is both distinct from health and related to it. Drawing on Barth's view that health is "strength for human life," he notes that social, political and economic systems all impact on human flourishing. He also insightfully argues that suffering, limitation, and even death are inescapable features of the human condition and so must be included in any theory of health. Drawing on Aquinas' view that transcendent ends must be included in our theology of human creaturely existence, he brings those ends to bear on his own understanding of flourishing and health. Messer argues that, theologically, bodily integrity is a good of human life and a contributor to its flourishing, but it is neither our ultimate good nor necessary for human flourishing. Our ultimate good is found in salvation in Christ and the eschatological fulfilment of human existence, and so health may be trumped by other concerns. Furthermore, we can find forms of flourishing in the midst of disability and infirmity, and even when facing death. Illness, suffering, and death are (relative) 
evils; but they also reveal the vulnerability, finitude, and dependence that inhere in human bodily existence. $^{10,11}$

Messer has contributed significantly to our understanding of medicine. Nonetheless, in light of the concerns I raised earlier, I believe he is mistaken to see health as the key to our understanding of medicine. We need an alternative theology of medicine that neither ignores questions of health and the alleviation of suffering nor is bound by them. I have presented such accounts elsewhere. ${ }^{12,13}$ Let me briefly rehearse the main lines of the argument before I return to the question of what Christian love might look like in a time of Ebola.

\section{A Theology of Medicine}

Medicine is primarily an expression of care for vulnerable human beings whose finitude and frailty have been exposed by physical or psychological ailment and whose ability to function in meaningful relationships have been compromised. Its goal is to care for such vulnerable people so as to demonstrate our solidarity with them as suffering persons and seek to enable them to return to a reasonable level of functioning in relationships. ${ }^{*}$ Theologically, medicine is an appropriate expression of a well-

\footnotetext{
* A word of clarification is in order. The forms of human vulnerability that medicine addresses are, broadly speaking, "health-related." It may seem, then, that health and healing ought to be seen as one of the goals of medicine. This, I think, is a mistake, for a number of reasons. First, as outlined earlier, there are many good instances of medical care that do not contribute to a person's health and healing (or the health of their community). Second, health is notoriously difficult to describe, let alone define, making it unsuitable as a yardstick for measuring the effectiveness of medical care. Third, treating it as the goal of medicine (or one of them) makes it the noun rather than the adjective in our descriptions and understandings of medicine. As an adjective it works very well: it describes the primary concern of medicine (care for vulnerable human beings), qualifying the kinds of care that might or might not be in medicine's purview. As a noun, it works poorly, as it distorts our understanding of medical practice and misdirects its aims.
}

formed community's care for vulnerable members of the community, a reflection of the character of God and an anticipation of the final transformation of all things to which God is drawing us and all things. Such a view emerges, I believe, from the shape of the biblical story.

\section{A biblical-theological rationale}

Creation grounds our quest for knowledge and skill in the orderly character of God and the world and establishes limits on the kind of technical mastery we should seek: we are finite creatures and always will be; there is no faithful escape from the exigencies of creatureliness. The brokenness of the world as it now is limits our capacity to know truly and to care faithfully, for we are as broken as the world we seek to understand. Yet it necessitates our attempt to understand the world and shapes our efforts to change it; for the God who both made and judges the world also seeks to redeem and transform us and calls human creatures to be agents of God's work of fixing a broken world. In Jesus' life, ministry (including his healing miracles), death, and resurrection, we see both the clearest expression of that transforming work and the anticipation of its final state. In him, we also hear the call to be transformed and mobilised in God's great free-making mission, as, enabled by the Spirit, we work to see glimpses of our final destiny and his perfect future in our fleeting and flawed projects.

Such a theological perspective requires that we understand the limits of our endeavours: any change we make to the world or needy people in it will be partial and temporary at best; we are still subject to death, and the world will only be made new by the sovereign work of God, not the labour of our hands. We build signposts to that final transformation, and occasionally plant oases on the road towards it: the garden-city for which we long and to which we seek to witness by word and deed will be the gift of God. ${ }^{14}$ 


\section{A Christian view of medicine and its practice}

Physical and psychological illness, injury, or disability are problems because they adversely affect people and interfere with their ability to function in relationships, exposing their vulnerability and diminishing their flourishing. Patients are in a position of relative weakness, requiring the doctor's knowledge and skill in caring for their frail flesh. ${ }^{15}$ This power differential generates a moral call: for Christians, power and privilege generate a corresponding responsibility to serve (Matt 20:25-28).

Medicine exists in and for a given community and aims to care for people in their weakness and vulnerability, deal with the disruption caused by disease processes, injury, or deformity, and return people to proper functioning in their relationships and as persons, as far as this is practicable. This both justifies the existence of medicine and establishes its goal. While fighting disease and improving a community's health are important, they are means rather than the ends of medicine. Medicine is a matter of health care, not of health care. Medicine's goal is to provide care for this frail flesh and, where this is possible and as far as this is practicable, to remove impediments to human flourishing, restoring people to proper personal and relational functioning. It is a primary expression of a community's commitment in solidarity to our vulnerable fellow humans, rather than abandoning them in their frailty. ${ }^{11,16}$

MacIntyre's notion of "social practice" contributes to our understanding of medicine. ${ }^{17,18}$ As a social practice, medicine has a set of institutional frameworks that foster the qualities and behaviours that count as good medical practice, aiming at achieving the goods that are internal to medicine as a profession, which arise out of the ends proper to it. As noted earlier, medicine's goal is not "health," but to care for vulnerable people in such a way that a doctor's expertise meets a patient's need. These needs are the result of physical or psychological disruptions to their ability to function well as persons in community. The aim of the doctor's care is the patient's restoration to a reasonable level of relational functioning, or when this is not possible, to enable them to cope as well as they can with their ailment. This is medicine's goal: the expression of appropriate care for vulnerable people. The nature of medicine reflects this. It is an expression of a community's solidarity with and care for its members whose inherent frailty has been exposed by physical or psychological disruption.

Such a perspective both articulates and enhances the moral character of medicine and enables us to resist the "technological imperatives" that can overwhelm personal concerns for the sake of technical possibilities. ${ }^{7,8,19}$ It also raises questions concerning what kind of medical care is appropriate in what circumstances and what justifies those decisions.

\section{Some Implications}

This vision of medicine has clear implications for its practice, both in the resourcerich individualistic consumerist West and the resource-constrained contexts in which the Ebola epidemic raged. Medicine not only expresses a particular vision of community, it also exists as a concrete expression of actual communities' care for their vulnerable members. A Christian vision of human community suggests that every society has the obligation to provide goods and services that enable its members to function well in it: to flourish, ${ }^{9}$ to enjoy a measure of shalom ${ }^{20}$. Medicine is one such service and is enabled by a given society's commitment to meet the health needs of its members. Indeed, the very existence of medicine, the training and ancillary services that doctors need to care for their patients, is funded by those communities. The range of health-care options available in the West outstrips the resources available even in those affluent societies, let alone those available in the "developing" world. This means it's important to consider the range of services that a society can be rightly expected to provide for its members.

This brings us to the notion of sustenance rights. Sustenance rights are those goods and services that a society must provide its members 
if they are to function as persons and in relationships. People are entitled to such basics as food, water, housing, education, and basic health care, for without these basics, people are unable to function meaningfully in relationships or pursue the goals of human existence - let alone enjoy shalom. ${ }^{20} \mathrm{~A}$ society may determine that it should provide more than these sustenance rights; but, it cannot rightly do less.

Health care sustenance rights, I would suggest, include community health resources and the services that are associated with a good general practice. A number of factors suggest this. First, medicine is an expression of a community's refusal to abandon its vulnerable members to their plight, but rather to stand alongside them in solidarity and care. Second, the clinical encounter between doctors with their knowledge and skill and patients in their need and vulnerability is at the heart of medical practice. Good GP services embody a community's solidarity with the vulnerable and provide care that might enable the relational dysfunctions occasioned by a patient's illness or infirmity to be overcome. What that general practice looks like will vary. Social and economic circumstances, other demands on a community's resources, and so on, will directly impinge on what can rightly be counted as a health care sustenance right.

A GP in suburban Australia will be able to refer his or her patient for sophisticated investigations in the immediate vicinity; in rural Australia, such services may be at the end of a four-hour drive. A rural health worker in Nepal or Angola is unlikely to have access to any investigations due to distance, time, cost, and even availability. A more basic level of medical treatment is appropriate. Nonetheless, all people are entitled to such services. We ought to be scandalised that even where a government notionally provides, say, rural health clinics, they are often under-resourced and/or under-, incompetently-, or even un-staffed. A Christian understanding of medicine sees this as intolerable.

Even so, it is important to recognise that there are many good and useful things that a community may provide for its members that go beyond sustenance rights. The kinds of services available in a tertiary level ICU require a degree of social infrastructure and capital investment that cannot be provided outside a major metropolis, and so, ipso facto, cannot be universally accessible. While it is not wrong for a community to provide them, I find it hard to see how such sophisticated services can be counted as an entitlement. They may be justified for some people in some circumstances, but only if providing them gives a reasonable chance of returning someone to a reasonable level of functioning in community and does not interfere with the provision of other sustenance rights. But that's another large question. ${ }^{21}$ Nonetheless, the level of basic care that counts as a sustenance right in a given community must be provided to all its members. This brings us back to the resource-constrained context with which I began. What does love look like in a time of Ebola?

\section{Conclusion: (Christian) love in a time of Ebola}

It seems to me that no Christian could rightly argue against providing basic medical services wherever people might live, be it New York or Free Town, no matter the circumstances. Our understanding of God and God's purposes, our theology of human community, require it. But healthcare is both complex and costly and is only one of a number of sustenance rights a community must provide. And so, if we are concerned about the provision of medical sustenance rights, we need to be equally concerned about the provision of the others. This also makes practical sense: for only in a stable society and a functional economy can resources be deployed to train doctors and sustain medical systems; only there will conditions exist in which patients can access - and trust - the services provided. Even those primarily concerned for medicine must care more broadly about the state of the societies and economies in which it's practiced. This is only reinforced when we remember that our concern for adequate medical services arises out of a concern for shalom, and 
that even a narrow focus on health requires an awareness of its social determinants.

Our vision of medicine, then, must encompass larger questions of justice within and between nations and economies, and acknowledge the bitterly ironic fact that, despite the scattered generosity of Western nations, the net flow of money and expertise (including trained doctors and nurses) is from the majority world to the West. ${ }^{22,23}$ Once again, medicine is not quarantined from bigger questions of justice and our responsibilities in a globalised world: any legitimate reflection on Christianity and medicine needs to come to grips with these broader question, and so, too, must our practice.

Let me return to our case-studies. While Brantly's was self-consciously an expression of Christian love and Khan's was not (at least, not to my knowledge), both men's commitment to the care of people with Ebola was not only justified from a Christian perspective, it was mandated, as was that of the women and men with whom they served. Questions have been raised about whether it is right, let alone required, for doctors to take such risks, and whether people outside these resource-constrained environments have an obligation to act. ${ }^{24}$ I fail to see how such risky action is other than an expression of love in a time of Ebola, and one that the Christian community is obliged to provide, as it has recognised throughout its history. ${ }^{25}$

A Christian vision of community requires that everyone is free to flourish: anything less falls far short of the shalom that is God's creational and redemptive purpose for human community. This is not bound by national borders, as if the country on our passport marks the boundaries of our care. Flourishing is God's intention for all human beings, for every human community. We are all diminished whenever we accept less than this for any of God's children. And so, while not all of us are called into medical mission, or the aid and development work with which it must be associated, some of us are. This is a representative, missional response to God's call on our communities.
This has implications for all of us: we who do not go have responsibilities to those who do. They are our representatives, signs to the world that God and God's people actually care about the love and fidelity and justice that we say are our ideals. And so when those who care fall prey to the conditions they seek to address, then we must care for them as if they were our own, as, in fact, they are. The seemingly extravagant cost of medical evacuation to tertiary hospitals gives them access to the services we enjoy and which they would otherwise have had. The treatment Brantly received was justified. So too, was the care Khan received, given his different circumstances. More to the point, so was the kind of care that they both sought to express in difficult and dangerous conditions of constraint.

So, while a willingness to risk life and wellbeing in caring for others is controversial and has been rejected by people from Galen to contemporary bioethicists, it has typified Christian care for the sick from the earliest times. Furthermore, it expresses something important about medicine and the cultural imagination that makes an enterprise like modern medicine possible. Whether or not it delivers desired health care outcomes, this is what love looks like in a time of Ebola.

\section{References}

1. WHO. Ebola situation report, 2015 November 4: WHO; 2015.

2. Marquez GG. Love in the time of Cholera. New York: Alfred A. Knopf; 1988.

3. A miraculous day. [Internet]. 2014 [cited 6 Nov 2015]. Available from:

http://www.samaritanspurse.org/article/samaritanspurse-doctor-recovered-from-ebola/

4. Profile: Leading Ebola doctor Sheik Umar Khan. [Internet]. 2014. [cited 6 Nov 2015]. Available from: http://www.bbc.com/news/world-africa-28560507

5. Baum F. The new public health. 3rd ed. South Melbourne: Oxford University Press; 2008. 
6. CDC. Global WASH fast facts.[Internet]. 2014 [cited 6 Nov 2015]. Available from: http://www.cdc.gov/healthywater/global/wash_statistic s.html

7. McKenny GP. To relieve the human condition: bioethics, technology, and the body. Albany: University of New York Press; 1997.

8. Shuman J, Volck B. Reclaiming the body: Christians and the faithful use of modern medicine. Grand Rapids: Brazos; 2006.

9. Messer NG. Flourishing: health, disease, and bioethics in theological perspective. Grand Rapids: Eerdmans; 2013.

10. MacIntyre A. Dependent rational animals: why human beings need the virtues. London: Duckworth; 1999.

11. Hauerwas S. Suffering presence: theological reflections on medicine, the mentally handicapped, and the church. Edinburgh: T\&T Clark; 1986.

12. Sloane A. Christianity and the transformation of medicine. In: Crisp OD, D’Costa G, Davies M, Hampson P, editors. Christianity and the disciplines: the transformation of the university. London: T\&T Clark; 2012:85-99.

13. Sloane A. Vulnerability and care: Christian reflections on the philosophy of medicine. London: Bloomsbury T\&T Clark; 2016.

14. Wright T. Surprised by hope. London: SPCK; 2007.

15. Pellegrino ED, Thomasma DC. Helping and healing: religious commitment in health care. Washington: Georgetown University Press; 1997.
16. Hauerwas S. Naming the silences: God, medicine, and the problem of duffering. Grand Rapids: Eerdmans; 1990.

17. MacIntyre A. After virtue: a study in moral theory. 2nd ed. Notre Dame: University of Notre Dame Press; 1984.

18. MacIntyre A. Whose justice? Which rationality? London: Duckworth; 1987.

19. Bishop JP. The anticipatory corpse: medicine, power and the care of the dying. Notre Dame, IN: UNDP; 2011.

20. Wolterstorff N. Until justice and peace embrace. Grand Rapids: Eerdmans; 1983.

21. Sloane A. Painful justice: an ethical perspective on the allocation of trauma services in Australia. The Aus and NZ Jf Surg. 1998;68:760-3.

22. The state of finance for developing countries. [Internet]. 2014. [cited 4 Nov 2016] Available from: http://eurodad.org/finance_for_developing_countries

23. Crisp N, Chen L. Global supply of health professionals. New Engl J Med. 2014;370:950-7 http://www.nejm.org/doi/full/10.1056/NEJMra111161 $\underline{0}$

24. Ebola: should doctors be forced to treat infected patients? [Internet]. 2014. [Cited 9 Nov 2015] Available fromP: http://www.theweek.co.uk/worldnews/ebola/60994/ebola-should-doctors-be-forced-totreat-infected-patients

25. Stark R. The rise of Christianity. New York: HarperCollins; 1996.

Peer Reviewed

Competing Interests: None declared.

Correspondence: Andrew Sloane, Morling College, Australia. AndrewS@morling.edu.au 
Cite this article as: Sloane A. Love in a time of Ebola - reflections on theology of medicine in resourcechallenged environments. Christian Journal for Global Health (May 2016), 3(1):77-85.

(C) Sloane A This is an open-access article distributed under the terms of the Creative Commons Attribution License, which permits unrestricted use, distribution, and reproduction in any medium, provided the original author and source are properly cited. To view a copy of the license, visit http://creativecommons.org/licenses/by/3.0/ 